\title{
EXTENTS OF SHARP PRACTICES IN CREDIT ALLOCATION AND UTILIZATION AMONG STAFF AND BENEFICIARIES OF THE BANK OF AGRICULTURE IN OYO STATE
}

\author{
Ladele, A.A, *Oyelami, B.O and Balogun, O.T \\ Department of Agric. Extension and Rural Development, University of Ibadan, Ibadan \\ ${ }^{*}$ Corresponding Author's e-mail:benjaminolusegun001@gmail.com
}

\begin{abstract}
One of the strategies employed in the implementation of Agricultural Transformation Agenda (ATA) is to harness the roles of major stakeholders along the nodes of agricultural value chain. Pivotal among these are the financial institutions, one of which is the Bank of Agriculture (BOA). However, financial institutions are not immune to the widespread incidence of sharp practices (SPS) and corruption that have crumbled similar laudable programmes. Thus, the extent of SPs in credit allocation and utilization among staff and beneficiaries of BOA in Oyo State was examined. Simple random sampling technique was employed to select 135 respondents comprising 110 beneficiaries and 25 officers of the BOA for the study from the total number of registered BOA beneficiaries and staff. Primary data were obtained through questionnaires and interview schedules and analysed using descriptive statistics - frequencies and percentages.

Of the beneficiaries, $39.7 \%$ and $52 \%$ of the credit officers were between the ages of 41 and 50 and $51.8 \%$ of the beneficiaries were livestock farmers. Credit diversion and breach of contractual agreement were major forms of SPs respondents engaged in. High rate of default as well as lateness in the disbursement of farm credit were major problems in credit allocation and utilization. In conclusion, most of the respondents had unfavourable perception towards SPs, showing that they know it is counter-productive. Ironically, they engaged in it. The study recommends appropriate mechanisms including thorough monitoring, reward and sanction should be used to curb the SPS.
\end{abstract}

Keywords: Credit allocation and utilisation, Sharp practices, Bank of Agriculture.

\section{INTRODUCTION}

Every segment of agricultural production requires the availability of adequate capital since capital determines access to all other resources on which farmers depend (Ayoola and Oboh, 2000). It has been shown that farm level credit if well applied, encourages capital formation and diversified agriculture, increases resource productivity, size of farm operations, innovations in farming, marketing efficiency, value added and net farm incomes (Nwagboet al., 1989). In fact according to 
Devi and Govt (2012), credit forms an important input which ensures adequate working capital as well as technological development for rural farmers. Its adequate and timely provision significantly increases agricultural output which leads to an increase in the economic development of the farming household.

However in Nigeria, findings have revealed that one of the major problems confronting small scale farmers is poor access to adequate capital even though they produce the bulk of domestic agricultural output (Eze and Ibekwe, 2007). Adebayo and Adeola (2008) in their study conducted in Surulere Local Government Area of Oyo State discovered that smallholders depended heavily on less viable sources of credit such as Esusu (credits from informal savings), credits obtained from relatives/friends and co-operative societies other than the government owned credit institutions. This is not in any way to deny the fact that some efforts have been made by Nigerian government to address the challenge of smallholders' access to credit over the years. The Nigerian government has established a number of schemes and institutions for financing agriculture such as the Agricultural Credit Guarantee Scheme Fund (ACGSF), Refinancing and Rediscounting Facility (RRF), Agricultural Credit Support Scheme (ACSS), Supervised Agricultural Loans Board, National Programme for Food Security, Nigerian Agricultural Insurance Corporation (NAIC) and the Bank of Agriculture (BOA). The Bank of Agriculture is dedicated primarily to agricultural financing at both the micro and macro levels as well as micro financing of small and medium scale enterprises.

Notwithstanding, the impact of this bank is yet to be felt as expected by its target beneficiaries due to a number of constraints. According to Okojie et al (2010), the lack of bank accounts, collateral, and information regarding the procedure for accessing credits from banks limit rural farmers' access to credit from formal institutions. Adejobi and Atobatele (2008) opined that loan default could limit access to credit, while Agnet (2004) posited that the complex mechanism of commercial banking is least understood by the small-scale farmers, and thus, limits their access. Philip et al (2009) stated that high interest rate and the short-term nature of loans with fixed repayment periods do not suit annual cropping, and thus constitute a hindrance to credit access. Oji (2007) further mentioned the location of banks in urban centres as a limiting factor, among others earlier mentioned.

However, beyond the afore-mentioned apparent constraints, another strong but often overlooked constraint which constitutes a challenge to the performance of BOA in Nigeria is the incidence of 
deceitful practices among the beneficiaries and staff of the bank. Rhaji and Fakayode (2009) affirmed that access to agricultural credit has been severely constrained in developing countries like Nigeria because of the level of deceitful practices perpetrated by corruptible government officials in the agricultural sector, the level of fraudulent acts and problems encountered in the Bank of Agriculture. Awoke (2004) reported that high rate of loan default even by farmers arising from misappropriation of fund procedures, loan diversion and unwillingness to repay loans has been threatening the sustainability of most public agricultural credit schemes in Nigeria. It is against this background that this study is investigating credit allocation and utilization among staff and beneficiaries of the bank of agriculture in Oyo State.

The objectives of the study are to:

I. identify the socio economic characteristics of the respondents

II. describe forms of sharp practices in credit allocation and utilization

III. determine perception of the respondents on sharp practices in credit allocation and utilization

IV. examine the effects of sharp practices on credit allocation and utilisation.

\section{METHODOLOGY}

The study was carried out in Oyo State which is an inland state in South-Western Nigeria. It has an estimated land area of 28,454 square kilometres. It is bounded in the west partly by Ogun State and partly by the Republic of Benin, in the east by Osun State, in the north by Kwara State and in the south by Ogun State. It was created in 1976 from the former Western State, and originally included Osun State, which was segregated in 1991. Oyo state is homogenous, mainly inhabited by the Yoruba ethnic group who are primarily agrarian but have a predilection for living in high density urban centres.

According to the 2006 Census, the Oyo State Population stood at 5,591,589 comprising 2,809,840 males and 2,781,749 females. The State is one of the most urbanized in the whole Federation. Besides Ibadan, there are four big towns with large population. They are Ogbomosho, Oyo, Iseyin and Saki. Other fairly big towns in the State are Igboho, Kishi, Igbo-ora, Okeho, Lalupon, Ilero, Eruwa, Igbeti, Lanlate, llora and Sepeteri. The population of the study comprises of all registered loan beneficiaries under the direct lending scheme and staff of the credit department in the three 
branches of the Bank of Agriculture in Oyo State. (Ibadan, Iseyin, Igbo-ora). Simple random sampling technique was used to select the total number of respondents for the study from the total number of registered beneficiaries and staff of BOA. Primary data were collected with aid of interviewer administered questionnaire which was administered to the respondents by the researcher. Both face validity and reliability tests were carried out to ascertain the appropriateness of the research instruments. A reliability coefficient of 0.90 was obtained using split-half method. Data collected were analysed using frequency counts and percentages.

Table I: Distribution of the selected population

\begin{tabular}{|l|l|l|l|l|}
\hline Branches & $\begin{array}{l}\text { Population of } \\
\text { registered } \\
\text { beneficiaries }\end{array}$ & $\begin{array}{l}\text { Population of staff } \\
\text { in the credit dept. }\end{array}$ & $\begin{array}{l}2 \% \text { of the } \\
\text { beneficiaries }\end{array}$ & $50 \%$ of the staff \\
Ibadan & 1380 & 11 & 28 & 5 \\
Igbo-ora & 2753 & 12 & 29 & 12 \\
\hline Iseyin & 1385 & 17 & 31 & 8 \\
\hline Total & 5509 & 51 & 110 & 25 \\
\cline { 3 - 5 } & & & & $\begin{array}{l}\text { Total Respondents : } \\
135\end{array}$ \\
\hline
\end{tabular}

Measurement of variables

Independent variables such as age, family size and years of farming experience was obtained as actual while others like sex, marital status, religion and level of education will be measured at nominal level. Forms of sharp practices was measured using a three point scale of Always (2), Occasionally (1) and Never (0) containing statements covering varied types of sharp practices such as bribery, favouritism, extortion, misappropriation of funds and undue preference. The dependent variable which is extent to which sharp practices pose a threat to credit allocation and utilisation was measured using a five point Likert type scale of Undecided(0), Little extent (1), Moderate extent (2), High extent (4) and Very high extent (4) containing varied statements designed to measure extent to which sharp practices pose threat. 


\section{RESULTSAND DISCUSSION}

\section{Socio-economic characteristics of respondents}

Table I reveals that about $40 \%$ and $50 \%$ of beneficiaries and credit officers fell within the age range of $41-50$ years respectively. This suggests that most of the respondents were young, active and had potential for productive activities if supported with adequate credit. This is in consonance with the findings of Adebayo and Adeola (2008) who both discovered that credit user are smallholders within the age range of $20-49$ years. This is however contrary to Ewuola and Williams (1995) that found that most loan beneficiaries in Ondo State were above average in age. Furthermore, the result reveals that most of the beneficiaries (48.1\%) had higher education which is contrary to the findings of Ewuola and Williams (1995) that found that their respondents possessed low level of education. The result further shows that there were more male beneficiaries (70.9\%) and credit officers (64\%). This implies that more males were involved in farming than females and had the time and strength to source for credits than their female counterparts. Osondu (2014) found access to credits as one of the major constraints to women embarking in non-farm entrepreneurship by women farmers. Majority of the beneficiaries (84.5\%) and credit officers (92\%) were married while $12.7 \%$ (Beneficiaries) and $8 \%$ (Credit Officers) of the respondents were single. This is in line with the findings of Akinbile and Aminu (2012) who reported that majority of farmers were respondent farmers to be married. The table revealed that many among the beneficiaries (48.1\%) had tertiary education, while all credit officers $(100 \%)$ had tertiary education. About half of the respondents (51.8\%) engaged in livestock production (poultry and fishery), 27.3\% engaged in arable farming while $20.9 \%$ engage in other forms of farming like processing and marketing of agricultural produce. This probably may be because livestock farmers are the most aggressive in credit pursuit due to the sensitive and capital intensive nature of their enterprise . 
Ladele, Oyelami \& Balogun

Table I: Distribution of respondents' selected socio-economic characteristics

( $\mathrm{n}$ of beneficiaries $=110, \mathrm{n}$ of credit officers $=25$ )

\begin{tabular}{|c|c|c|}
\hline 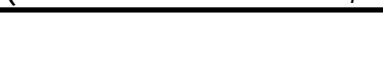 & Beneficiaries & Credit officers \\
\hline Variables & Frequency & Frequency \\
\hline $\begin{array}{l}\text { Age } \\
21-30 \\
31-40 \\
41-50 \\
51-60 \\
61-70\end{array}$ & $\begin{array}{l}6(5.5) \\
37(33.6) \\
45(39.7) \\
19(17.3) \\
5(4.5)\end{array}$ & $\begin{array}{l}0(0) \\
11(44.0) \\
13(52.0) \\
1(4) \\
0(0)\end{array}$ \\
\hline $\begin{array}{l}\text { Sex } \\
\text { Male } \\
\text { Female }\end{array}$ & $\begin{array}{l}78(70.9) \\
32(29.1)\end{array}$ & $\begin{array}{l}16(54) \\
9(36)\end{array}$ \\
\hline $\begin{array}{l}\text { Marital status } \\
\text { Single } \\
\text { Married } \\
\text { Widowed }\end{array}$ & $\begin{array}{l}14(12.7) \\
93(84.5) \\
3(2.7)\end{array}$ & $\begin{array}{l}2(8) \\
23(92) \\
0(0)\end{array}$ \\
\hline $\begin{array}{l}\text { Religion } \\
\text { Christianity } \\
\text { Islam } \\
\text { Traditional }\end{array}$ & $\begin{array}{l}69(62.7) \\
40(36.4) \\
1(0.9)\end{array}$ & $\begin{array}{l}18(72) \\
7(28) \\
0(0)\end{array}$ \\
\hline $\begin{array}{l}\text { Level of education } \\
\text { No formal education } \\
\text { Primary education } \\
\text { Secondary education } \\
\text { Tertiary education }\end{array}$ & $\begin{array}{l}31(28.1) \\
6(5.5) \\
20(18.2) \\
53(48.1)\end{array}$ & $\begin{array}{l}0(0) \\
0(0) \\
0(0) \\
25(100)\end{array}$ \\
\hline $\begin{array}{l}\text { Form of farming } \\
\text { Arable } \\
\text { Livestock } \\
\text { Others }\end{array}$ & $\begin{array}{l}30(27.3) \\
57(51.8) \\
23(20.9)\end{array}$ & $\begin{array}{l}- \\
- \\
-\end{array}$ \\
\hline $\begin{array}{l}\text { Other source of credit } \\
\text { Friend \& relatives } \\
\text { Esusu(informal savings) } \\
\text { Local money lender } \\
\text { Cooperatives } \\
\text { Commercial banks } \\
\text { Microfinance banks } \\
\text { None }\end{array}$ & $\begin{array}{l}14(12.7) \\
2(1.8) \\
1(0.9) \\
21(19.1) \\
5(4.5) \\
4(3.6) \\
63(57.3)\end{array}$ & $\begin{array}{l}- \\
- \\
- \\
- \\
- \\
-\end{array}$ \\
\hline
\end{tabular}

Source: Field Survey, 2012.

Note: Percentages are in parenthesis 
Forms of sharp practices in credit allocation

Table $2 a$ revealed that $24.5 \%$ of the beneficiaries claimed that credit officers occasionally show favouritism during credit processing, allocation and disbursement, while $11.8 \%$ of the beneficiaries indicated that they usually give gifts to credit officers so as to fast-track the farm credit disbursement process. On the other hand, $27.3 \%$ and $28.2 \%$ of the beneficiaries opined that bribery and undue preferences were occasionally practiced in the course of credit allocation and disbursement. This is in agreement with Adeniji and Joshua (2008) who reported that credit officers do not thoroughly supervise beneficiaries' agricultural projects due to shady deals by some of their corrupt officers.

Table $2 \mathrm{~b}$ shows that most (44\%) of the credit officers indicated breach of contractual agreements as one of the forms of sharp practices frequently practiced by beneficiaries after obtaining farm credit. This finding is in line with Adeniji and Joshua (2007) who asserted that breach of contractual agreements is high due to poor supervision from the bank employees. Also, many (68\%) of the credit officers opined that beneficiaries occasionally divert farm credit to unproductive ventures. Oluwasola and Alimi (2007) mentioned the likelihood of credit diversion to non-farm activities. However, majority (68\%) of the credit officers stated that bribery is never a form of "sharp practice" among beneficiaries, claiming that beneficiaries do not engage in this act as they may be sanctioned by the credit institution. 
Table 2a: Distribution of beneficiaries according to forms of sharp practices in credit

\begin{tabular}{|c|c|c|c|}
\hline \multirow[t]{2}{*}{ STATEMENTS } & Never & Occasionally & Always \\
\hline & Freq. (\%) & $\begin{array}{l}\text { Freq. } \\
(\%)\end{array}$ & $\begin{array}{l}\text { Freq. } \\
(\%)\end{array}$ \\
\hline $\begin{array}{l}\text { Farmers A and B apply for farm credit in Mr Z's bank. } \\
\text { Farmer B meets the requirements for collecting the farm } \\
\text { credit but Mr Z grants it to Mr A because they are } \\
\text { friends.(Favouritism) }\end{array}$ & $75(68.2)$ & $27(24.5)$ & $8(7.30)$ \\
\hline $\begin{array}{l}\text { Mrs B was to acquire farm credit from the credit institution } \\
\text { so she offers to buy the credit officers recharge cards in } \\
\text { order to speed up the credit disbursement } \\
\text { process.(Bribery) }\end{array}$ & $63(60.9)$ & $30(27.3)$ & $13(11.8)$ \\
\hline $\begin{array}{l}\text { Farmer } X \text { is not qualified to collect farm credit for his fish } \\
\text { farming business because he does not have all the } \\
\text { required documents, he offers to buy a GSM phone for the } \\
\text { credit official and he eventually gets the farm credit. } \\
\text { (Bribery) }\end{array}$ & $89(80.9)$ & $17(15.5)$ & $4(3.6)$ \\
\hline $\begin{array}{l}\text { Farmer M was asked to pay certain fees to the credit } \\
\text { officer before the disbursement of farm credit or forfeit the } \\
\text { farm credit.(Extortion) }\end{array}$ & $90(81.8)$ & $13(11.8)$ & $7(6.4)$ \\
\hline $\begin{array}{l}\text { Mr D, a bank official invested a part of the money for cred it } \\
\text { allocation into his personal account to yield more interest } \\
\text { for some time before disbursing to } \\
\text { beneficiaries.(Misappropriation of funds) }\end{array}$ & $81(73.6)$ & $21(19.1)$ & $8(7.2)$ \\
\hline $\begin{array}{l}\text { Mr TJ, a credit officer prefers to allocate farm credit to } \\
\text { livestock farmers than arable farmers because livestock } \\
\text { farmers pay back on time. (undue preference) }\end{array}$ & $77(70.0)$ & $31(28.2)$ & $2(1.8)$ \\
\hline
\end{tabular}

Source: Field Survey, 2012

Note; percentages are in parenthesis 
Table 2b: Distribution of credit officers according to forms of sharp practices in credit utilization

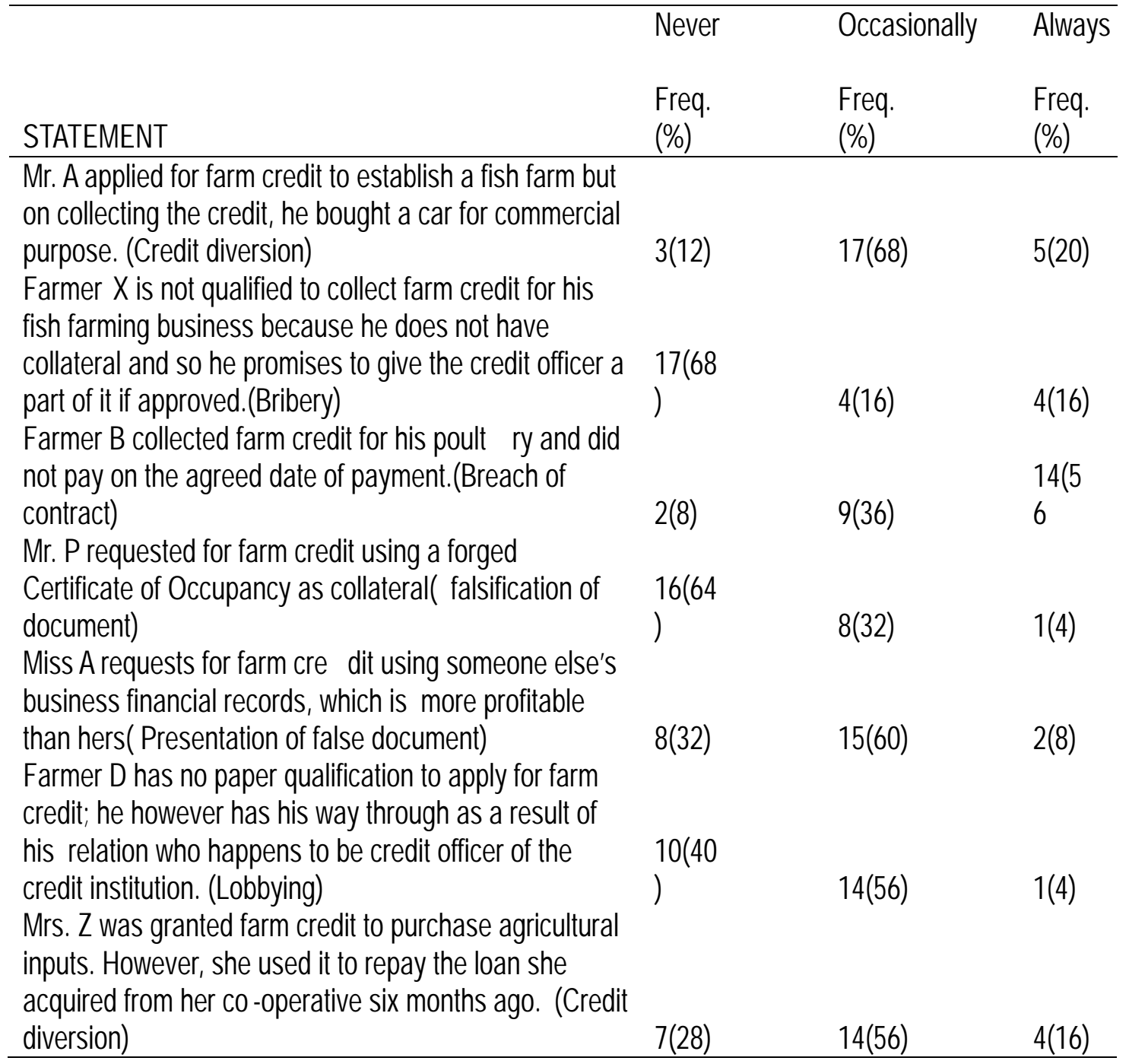

Source: Field Survey, 2012

Note: percentages are in parenthesis 
Perception of respondents' on sharp practices

Table 3 reveals perception of respondents on sharp practices. A large proportion (57.3\%) of beneficiaries of BOA had a favourable perception about sharp practices. This implies that they saw nothing bad about it and are more interested in accessing loan than to follow due process. However, most (64\%) of BOA staff had an unfavourable perception about sharp practices mainly because they could appreciate its implications better

Table 3: Distribution of respondents based on their perception on sharp practices

\begin{tabular}{llllll}
\hline Category of & Favourable & Unfavourable & Minimum & Maximum & Mean \\
perception & Freq. & Freq. & & & \\
& $(\%)$ & $(\%)$ & & & \\
Beneficiaries & $63(57.3)$ & $47(42.7)$ & 36 & 75 & 50.50 \\
Credit officers & $9(36)$ & $16(64)$ & 37 & 58 & 48.44 \\
\hline
\end{tabular}

Source: Field Survey, 2012.

Note: percentages are in parenthesis

Effects of sharp practices on farm credit provision by beneficiaries

Table 4a shows that a large proportion (47.3\%) of the respondents attested that embezzlementis one of the sharp practices that pose a threat to farm credit provision at a very high extent. Farmers are aware that the capital made available is meant to be revolving, if embezzled, this will frustrate the whole essence of the scheme. Moreover, $43.6 \%$ of the respondents indicated that misappropriation of farm credit pose a threat to a high extent in credit provision. A few numbers of the beneficiaries (15.5\%) was of the opinion that giving undue preference and showing favouritism to intending beneficiaries will not pose a threat to the provision of farm credit.

The table further shows that $28.2 \%$ of the beneficiaries indicated that nepotism would pose a threat to credit provision to a high extent. This implies that giving undue preferences to intending beneficiaries on the basis of personal relationships rather than on merit will threaten the provision of farm credit. Also, a large proportion (55.5\%) of the respondents was of the opinion that the breach of 
contractual agreement by beneficiaries would pose a threat to credit provision to a very high extent. The implication of this is that failing to comply with the terms of contract given by the credit institution could make loan recovery process by the credit officers a difficult task resulting in a high rate of default.

Table 4a: Distribution of beneficiaries based on effects of sharp practices on farm credit provision

\begin{tabular}{|c|c|c|c|c|c|}
\hline STATEMENTS & $\begin{array}{l}\text { Undecided } \\
\text { Freq. } \\
(\%)\end{array}$ & $\begin{array}{l}\text { Little Extent } \\
\text { Freq. } \\
(\%)\end{array}$ & $\begin{array}{l}\text { Moderate } \\
\text { Extent } \\
\text { Freq. } \\
(\%) \\
\end{array}$ & $\begin{array}{l}\text { High Extent } \\
\text { Freq. } \\
(\%)\end{array}$ & $\begin{array}{l}\text { Very High } \\
\text { Extent } \\
\text { Freq. } \\
(\%) \\
\end{array}$ \\
\hline \multicolumn{6}{|l|}{$\begin{array}{l}\text { Using agricultural credit allocated for non - } \\
\text { agricultural purposes(credit diversion) }\end{array}$} \\
\hline Collection of agricultural credit to service & 14(12.7) & $4(3.6)$ & 15(13.6) & $39(35.5)$ & $38(34.5)$ \\
\hline other loans(credit diversion) & $18(16.4)$ & $3(2.7)$ & 19(17.3) & $40(36.4)$ & $30(27.3)$ \\
\hline $\begin{array}{l}\text { Giving undue preferences to beneficiaries } \\
\text { (nepotism) }\end{array}$ & $17(15.5)$ & $16(14.5)$ & $26(23.6)$ & $31(28.2)$ & $20(18.2)$ \\
\hline $\begin{array}{l}\text { Close friend are mostly preferred in the } \\
\text { process of loan disbursement to others } \\
\text { who are more qualified(influence } \\
\text { peddling) }\end{array}$ & $17(15.5)$ & $20(18.2)$ & $16(14.5)$ & $21(19.1)$ & $36(32.7)$ \\
\hline Misappropriation of agricultural credit & $10(9.1)$ & $12(10.9)$ & $11(10)$ & $48(43.6)$ & $29(26.4)$ \\
\hline $\begin{array}{l}\text { Breach of contractual agreement } \\
\text { Documents that are not genuine are used } \\
\text { to request for agricultural }\end{array}$ & $16(14.5)$ & $10(9.1)$ & $23(20.9)$ & $41(37.3)$ & 20(18.2) \\
\hline credit(falsification of documents) & $21(19.1)$ & $19(17.3)$ & $27(24.5)$ & $25(22.7)$ & 18(16.4) \\
\hline $\begin{array}{l}\text { False collateral } \\
\text { Giving financial gifts to facilit ate the }\end{array}$ & $27(24.5)$ & $13(11.8)$ & $27(24.5)$ & $28(25.5)$ & $15(13.6)$ \\
\hline approval of farm credit (bribery) & $29(26.4)$ & $21(19.1)$ & $17(15.5)$ & $25(22.7)$ & 18(16.4) \\
\hline Presentation of fake identity & $22(20)$ & $13(11.8)$ & $18(16.4)$ & $16(14.5)$ & $41(37.3)$ \\
\hline Embezzlement & $24(21.8)$ & $5(4.5)$ & $9(8.2)$ & $20(18.2)$ & $52(47.4)$ \\
\hline Extortion & $27(24.5)$ & $8(7.3)$ & $8(7.3)$ & $32(29.1)$ & $35(31.8)$ \\
\hline Lobbying & $23(20.9)$ & $13(11.8)$ & $14(12.7)$ & $19(17.3)$ & $41(37.3)$ \\
\hline $\begin{array}{l}\text { Release of agricultural credit to "ghost" } \\
\text { farmers }\end{array}$ & $34(30.9)$ & $9(8.2)$ & 13(11.8) & 19(17.3) & $35(31.8)$ \\
\hline
\end{tabular}

Source: Field Survey, 2012 


\section{Effects of sharp practices on farm credit provision by credit officers}

Table $4 \mathrm{~b}$ shows that a small proportion (16\%) of the respondents agreed that collection of agricultural credit to service other loans as well as breach of contractual agreement would be a threat to the provision of farm credit to a very high extent. This implies that these forms of sharp practices will affect the rate of default in repayment of farm credit thereby leading to credit rationing to other intending beneficiaries. Also, $32 \%$ of the respondents opined that giving financial gifts to facilitate the approval of farm credit will pose a threat to the provision of farm credit to a little extent. The implication of this is that many respondents do not perceive this as a form of "sharp practice" but see it as a means to show appreciation for rendering assistance in the course of credit disbursement.

Furthermore, table $4 \mathrm{~b}$ reveals that $44 \%$ of the respondents were of the opinion that diversion of farm credit by beneficiaries would pose as threat to the provision of credit to a high extent. This suggests that credit diversion to unproductive ventures would affect the disbursement of farm credit to other intending beneficiaries who may want to apply for loans subsequently. 
Table 4b: Distribution of credit officers based on effects of sharp practices on farm credit provision

\begin{tabular}{|c|c|c|c|c|c|}
\hline \multirow[t]{2}{*}{ STATEMENTS } & $\begin{array}{l}\text { Not } \\
\text { Applicable }\end{array}$ & $\begin{array}{l}\text { Little } \\
\text { Extent }\end{array}$ & $\begin{array}{l}\text { Moderate } \\
\text { Extent }\end{array}$ & $\begin{array}{l}\text { High } \\
\text { Extent }\end{array}$ & $\begin{array}{l}\text { Very High } \\
\text { Extent }\end{array}$ \\
\hline & $\begin{array}{l}\text { Freq. } \\
(\%)\end{array}$ & $\begin{array}{l}\text { Freq. } \\
(\%)\end{array}$ & $\begin{array}{l}\text { Freq. } \\
(\%)\end{array}$ & $\begin{array}{l}\text { Freq } \\
(\%)\end{array}$ & $\begin{array}{l}\text { Freq } \\
(\%)\end{array}$ \\
\hline $\begin{array}{l}\text { Using agricultural credit allocated for non - } \\
\text { agricultural purposes(credit diversion) }\end{array}$ & $3(12)$ & $2(8)$ & $6(24)$ & $\begin{array}{l}11(4 \\
4\end{array}$ & $3(12$ \\
\hline $\begin{array}{l}\text { Collection of agricultural credit to service } \\
\text { other loans(credit diversion) }\end{array}$ & $0(0)$ & $6(24)$ & $7(28)$ & $8(32$ & $4(16$ \\
\hline $\begin{array}{l}\text { Giving undue preferences to beneficiaries } \\
\text { (nepotism) }\end{array}$ & $4(16)$ & $3(1)$ & $4(16)$ & $\begin{array}{l}11(4 \\
4)\end{array}$ & $3(12$ \\
\hline $\begin{array}{l}\text { Close friend are mostly preferred in the } \\
\text { process of loan disbursement to others who } \\
\text { are more qualified(influence peddling) }\end{array}$ & $5(20)$ & $4(16)$ & $3(12)$ & )$^{9}(36$ & $\begin{array}{l}4(16 \\
)\end{array}$ \\
\hline Misappropriation of agricultural credit & $2(8)$ & $7(28)$ & $5(20)$ & $3(12$ & $8(32$ \\
\hline Breach of contractual agreement & $1(4)$ & $4(16)$ & $1(4)$ & $\begin{array}{l}15(6 \\
0\end{array}$ & $4(16$ \\
\hline $\begin{array}{l}\text { Documents that are not genuine are used to } \\
\text { request for agricultural credit(falsification of } \\
\text { documents) }\end{array}$ & $6(24)$ & $5(20)$ & $3(12)$ & $\begin{array}{l}5(20 \\
)\end{array}$ & $\begin{array}{l}6(24 \\
)\end{array}$ \\
\hline False collateral & $10(40$ & $4(16)$ & $0(0)$ & $\begin{array}{l}5(20 \\
)\end{array}$ & $\begin{array}{l}6(24 \\
)\end{array}$ \\
\hline $\begin{array}{l}\text { Giving financial gifts to facilitate the approval } \\
\text { of farm credit(bribery) }\end{array}$ & $7(28)$ & $8(32)$ & $1(4)$ & $\begin{array}{l}4(16 \\
)\end{array}$ & $\begin{array}{l}5(20 \\
)\end{array}$ \\
\hline Presentation of fake identity & )$^{11(44}$ & $2(8)$ & $2(8)$ & $\begin{array}{l}4(16 \\
)\end{array}$ & $\begin{array}{l}6(24 \\
)\end{array}$ \\
\hline Embezzlement & $9(36)$ & $4(16)$ & $1(4)$ & $3(12$ & $8(32$ \\
\hline Extortion & $4(16)$ & $9(36)$ & $2(8)$ & $3(12$ & $7(28$ \\
\hline Lobbying & $4(10)$ & $6(24)$ & $5(20)$ & $5(20$ & $5(20$ \\
\hline $\begin{array}{l}\text { Release of agricultural credit to "ghost" } \\
\text { farmers }\end{array}$ & $5(20)$ & $9(36)$ & $4(16)$ & $2(8)$ & $\begin{array}{l}5(20 \\
)^{2}\end{array}$ \\
\hline
\end{tabular}

Source: Field Survey, 2012 


\section{CONCLUSION AND RECOMMENDATIONS}

This study has established the incidence of some forms of sharp practices in the process of farm credit allocation and utilization. These forms of sharp practices include favouritism, credit diversion, undue preference, bribery, extortion, and the like. All these sharp practices pose threat to the provision of farm credit as well as agricultural development. It is therefore recommended that BOA staff should ensure stricter adherence to due process before disbursing loans to farmers and intending beneficiaries. Moreover, the credit institution should develop sound monitoring and inspection system by regular visits of the field officers to their respective clients and inspections of BOA staff activities to reduce sharp practices to the barest minimum. Besides, legal sanctions and appropriate punitive measures should be applied to perpetrators of sharp practices and willful defaulters.

\section{REFERENCES}

Adebayo O.O and Adeola R.G. (2008) "Sources and Uses of Agricultural Credit by Small Scale Farmers in Surulere Local Government Area of Oyo State" International Journal of Contemporary and Applied Studies of Man.10(4):313-314.

Adejobi O. and AtobateleJ. T. (2008) "An analysis of loan delinquency among small-scale farmers in south-western Nigeria: Application of logit and loan performance indices". East-African Agricultural and Forestry Journal. 74 (3): 68-71

Adeniji, O.B. and Joshua A.O. (2008). Evaluation of Loan Disbursement and Repayment of Supervised Credit Scheme of Nigeria Agricultural Cooperative and Rural Development Bankin Zaria and Kaduna North Local Government Areas of Kaduna State, Nigeria.

Agnet.(2004) Makingfarm credit work for the small-scale farmers. http://www.agnet.org/library/nc/145b/Accessed on July 20, 2010

Akinbile L.A. and Aminu O.O. (2012) "Farmers' perception of potentials of Jatrophacurcas in mitigating effects of climate change in Owo Local Government Area of Ondo State". Nigerian Journal of Rural Sociology.13 (1):9-18

Ayoola G.B. and Oboh V.U. (2000) "A model of public expenditure to reveal the preference for agriculture in the budget". Journal of Rural Economic Development. 14(1):56-73.

Awoke, M. U. (2004) "Factors affecting loan acquisition and repayment patterns of small holder farmers in Ika North West of Delta State, Nigeria".Journal of Sustainable Tropical Agriculture Research. 9:61-64. 
Devi R. U. and Govt S.R.K. (2012).The Role of Credit Co-operatives in the Agricultural Development of Andhra Pradesh, India. International Journal of Cooperative Studies. $1(2): 55-64$.

Eze, C.C. and Ibekwe U.C. (2007) "Determinants of loan repayment under the indigenous financial system in South Eastern Nigeria". Journal of Social Sciences 2(2):116-120.

Ewuola S.O. and S.K.T. Williams (1995). Effects of Institutional borrower characteristics on loan recovery: A study of Ondo State Agricultural credit corporation. Agrosearch.1(2): 109 116.

Nwagbo E.C., Ilebani D. and Erhabor P.O. (1989) "The role of credit in agricultural development: a case study of small-scale food production in Ondo State, Nigeria". Journal of Agricultural Education3(1\&2): 29-35.

Okojie, C., A. Monye-Emina, K. Eghafona, G. Osaghae,and J.O. Ehiakhamen. 2010. Institutional environmentand access to microfinance by self-employed women inthe rural areas of Edo State. NSSP Brief No. 14. Washington. D.C.: International Food Policy Research Institute.

Oluwasola, O. and Alimi, T. (2007): Financial intermediation in agriculture in Nigeria: Emerging role of Non-Governmental Organisations. Agrosearch. 9(1\&2): 43-51

Oji, K.O. Policy needs in the microfinance sector: The missing angle. In Policy Challenges for Microfinance Design and Practice in Nigeria, Enugu Forum Policy Paper 7.eds. Eboh, E.C., S. Ukeje, C. Ibe, and K. Ikpo. African Institute for Applied Economics.http://www.aiaenigeria.org/Publications/Policypaper7.pdf

Osondu, C. K. (2014) Determinants of decision for non-farm entrepreneurship by women farmers in Ikwuano LGA, Abia State.Agrosearch14(2): 154-167.

Phillip .D., Nkonya E., Pender J. and Oni O.A. ( 2009) Constraints to increasing agricultural productivity in Nigeria: A review. Nigeria Strategy Support Program (NSSP) Background Paper No.International Food Policy Research Institute NSSP 006:pp6

Rahji M.A.Y. andFakayode S.B. (2009) "A Multinomial Logit Analysis of Agricultural Credit Rationing by Commercial Banks in Nigeria. "InternationalJournal of Finance and Economics 16(1): 325-350 